\title{
Predictive value of in vitro assays depends on the mechanism of toxicity of metal oxide nanoparticles
}

Wan-Seob Cho ${ }^{1,2}$, Rodger Duffin ${ }^{1}$, Mark Bradley ${ }^{3}$, Ian L Megson ${ }^{4}$, William MacNee', Jong Kwon Lee ${ }^{5}$, Jayoung Jeong ${ }^{5}$ and Ken Donaldson ${ }^{1 *}$

\begin{abstract}
Background: Hazard identification for risk assessment of nanoparticles (NPs) is mainly composed of in vitro cellbased assays and in vivo animal experimentation. The rapidly increasing number and functionalizations of NPs makes in vivo toxicity tests undesirable on both ethical and financial grounds, creating an urgent need for development of in vitro cell-based assays that accurately predict in vivo toxicity and facilitate safe nanotechnology.

Methods: In this study, we used 9 different $\mathrm{NPs}\left(\mathrm{CeO}_{2}, \mathrm{TiO}_{2}\right.$, carbon black, $\mathrm{SiO}_{2}, \mathrm{NiO}, \mathrm{CO}_{3} \mathrm{O}_{4}, \mathrm{Cr}_{2} \mathrm{O}_{3}, \mathrm{CuO}$, and $\left.\mathrm{ZnO}\right)$. As an in vivo toxicity endpoint, the acute lung inflammogenicity in a rat instillation model was compared with the in vitro toxicity endpoints comprising cytotoxicity, pro-inflammatory cytokine expression, or haemolytic potential. For in vitro assays, 8 different cell-based assays were used including epithelial cells, monocytic/macrophage cells, human erythrocytes, and combined culture.

Results: $\mathrm{ZnO}$ and $\mathrm{CuO}$ NPs acting via soluble toxic ions showed positive results in most of assays and were consistent with the lung inflammation data. When compared in in vitro assays at the same surface area dose $\left(30 \mathrm{~cm}^{2} / \mathrm{mL}\right)$, NPs that were low solubility and therefore acting via surface reactivity had no convincing activity, except for $\mathrm{CeO}_{2} \mathrm{NP}$. Cytotoxicity in differentiated peripheral blood mononuclear cells was the most accurate showing $89 \%$ accuracy and $11 \%$ false negativity in predicting acute lung inflammogenicity. However, the haemolysis assay showed 100\% consistency with the lung inflammation if any dose, having statistical significance was considered positivity. Other cell-based in vitro assays showed a poorer correlation with in vivo inflammogenicity.
\end{abstract}

Conclusions: Based on the toxicity mechanisms of NPs, two different approaches can be applied for prediction of in vivo lung inflammogenicity. Most in vitro assays were good at detecting NPs that act via soluble ions (i.e., ZnO and (UO NP). However, in vitro assays were limited in detecting NPs acting via surface reactivity as their mechanism of toxicity, except for the haemolysis assay.

Keywords: In vitro, In vivo, Inflammation, Mechanism, Nanoparticles, Prediction, Toxicity

\footnotetext{
* Correspondence: ken.donaldson@ed.ac.uk

${ }^{1}$ ELEGI/Colt Laboratory, Centre for Inflammation Research, University of

Edinburgh, 47 Little France Crescent, Edinburgh EH16 4TJ, UK

Full list of author information is available at the end of the article
} 


\section{Background}

Metal oxide nanoparticles (NPs) have been used in various applications including industrial, electrical, pharmaceutical, and biomedical fields because of their unique physicochemical properties compared to bulk chemicals [1]. The high production volume of NPs and increasing numbers of functionalized versions constitutes a burden for toxicity testing and risk assessment for NP exposures [2]. In response to increasing concerns about the safety of manufactured nanomaterials, OECD (Organisation for Economic Co-operation and Development) launched an internationally harmonised programme about hazard, exposure, and risk assessment of nanomaterials in 2006 [3]. After six years of work, the OECD has come to conclusion that the current testing approaches are generally acceptable for nanomaterials although some adoptions may be necessary for the certain Test Guidelines [4].

Current hazard identification for risk assessment of NPs is mainly conducted with the aid of both in vivo and in vitro toxicity approaches. In vivo animal experimentation is more informative than in vitro experimentation, but there are major ethical and financial limitations to the in vivo approach [5]. Therefore, in vitro assay have been suggested as an alternative method to in vivo testing; indeed in vitro experiments are often used as an initial screen for the toxicity of substances and evaluation of their toxic mechanisms. There are several in vitro cell-based testing methods that are frequently used in this setting, including some assays which combine several cell types [6], and others that use differentiated macrophages from monocytic cells, which are more sensitive to weak stimuli [7]. However, in recent studies comparing several cell lines, cells were found to respond differently to NPs depending on the physiological functions and activities of cells $[8,9]$ and failed to predict the in vivo lung inflammogenicity [10]. However, those studies were performed with a limited number of particles and cell assays; more profound studies are essential to correlate in vitro and in vivo toxicity assays.

There are several critical factors that can produce discrepancies between studies. Dose is one of the most important factors when comparing several in vitro assays with in vivo assays, because even NPs with low toxicity can be toxic at high doses [11]. Surface area has been suggested as an appropriate dose metric in nanotoxicology rather than mass [12]. In addition to surface area metric, the dispersion of NPs is very important because highly agglomerated NPs showed less toxicity or inflammogenicity compared to well-dispersed NPs [13]. Determining the target organ for NP exposure is also important for selection of appropriate cell types for in vitro assays.

In this study, we were concerned with inhalation exposure of metal oxide NPs in occupational or consumer settings and we therefore used an acute lung inflammation model by intratracheal instillation into the lungs of rats. By comparison, we chose to investigate the nanotoxicity of the same panel of NPs in lung alveolar and bronchial epithelial cells and monocytic or macrophage cells to mimic the in vivo lung environment, using a range of in vitro toxicity tests.

\section{Results}

\section{Characterization of NPs}

Table 1 summarize the characterization of NPs including primary size, hydrodynamic size, and surface area. All NPs in PBS formed agglomerates, which required sonication to be dispersed. However, inclusion of 5\% fetal bovine serum in the PBS, particles formed smaller agglomerates that were readily dispersed because of the protein corona on the surface of NPs. All NPs and FBS showed endotoxin levels below the detection limit.

\section{A549 cells}

$\mathrm{Cr}_{2} \mathrm{O}_{3}, \mathrm{ZnO}$, and $\mathrm{CuO}$ NPs showed significant cytotoxicity (cell death measured by LDH levels or trypan blue staining) compared with vehicle control whilst other NPs had little or no toxic effect in this assay at the doses tested $\left(30-300 \mathrm{~cm}^{2} / \mathrm{mL}\right.$ for most NPs, $3-30 \mathrm{~cm}^{2} / \mathrm{mL}$ for $\mathrm{ZnO}$ and $\mathrm{CuO}$; Figure $1 \mathrm{~A}$ ). The levels of IL-8 proteins in the supernatant were significantly increased by both $\mathrm{ZnO}$ and $\mathrm{CuO} \mathrm{NP}$ (Figure 1B). Note that $\mathrm{ZnO}$ and $\mathrm{CuO}$ NP were the most cytotoxic and stimulatory for IL-8 although they were used at doses 10 -fold less than the other NPs.

\section{6-HBE cells}

Only $\mathrm{ZnO}$ and $\mathrm{CuO}$ NP exposure significantly increased cytotoxicity to 16-HBE cells (Figure 2A). The levels of IL-8 proteins were significantly increased by $\mathrm{CeO}_{2}$, carbon black (CB), and $\mathrm{ZnO} \mathrm{NP}$ and significantly decreased by $\mathrm{TiO}_{2} \mathrm{NP}$ at the high dose (Figure $2 \mathrm{~B}$ ).

\section{Monocytic THP-1 cells}

$\mathrm{Cr}_{2} \mathrm{O}_{3}$ and $\mathrm{CuO}$ NP exposure significantly increased cytotoxicity, whilst other NPs showed no differences compared to vehicle control (Figure 3A). The levels of IL-1 $\beta$ protein significantly increased only with $\mathrm{TiO}_{2} \mathrm{NP}$ treatment (Figure 3B).

\section{Alveolar macrophages}

Rat alveolar macrophages showed greater sensitivity to NPs compared to cell lines. All NPs excluding CB and $\mathrm{SiO}_{2}$ showed significant cytotoxicity compared to vehicle control (Figure 4A). In comparison with cytotoxicity, the levels of IL-1 $\beta$ showed marginal responses which only $\mathrm{TiO}_{2}$ and $\mathrm{CuO}$ NP showing significant increases (Figure 4B), although it should be noted that the $\mathrm{TiO}_{2}$ 
Table 1 Physicochemical properties of the panel of nanoparticles

\begin{tabular}{lllll}
\hline $\mathbf{N P}^{\mathbf{a}}$ & Primary size $(\mathbf{n m})^{\mathbf{b}}$ & Surface area $\left(\mathbf{m}^{\mathbf{2}} \mathbf{g}\right)^{\mathbf{c}}$ & Hydrodynamic size $(\mathbf{n m})$ in $\mathbf{5 \%}$ FBS & $\mathbf{M a s s}_{(\boldsymbol{\mu g}) \mathbf{f o r} \mathbf{3 0} \mathbf{c m}^{\mathbf{2}}}$ \\
\hline $\mathrm{CeO}_{2}$ & $9.7 \pm 0.4$ & 24.1 & $69.3 \pm 8.0$ & 125 \\
$\mathrm{TiO}_{2}$-rutile & $30.5 \pm 1.8$ & 27.5 & $89.9 \pm 13.1$ & 109 \\
$\mathrm{CB}$ & $15.3 \pm 6.0$ & 254 & $45.1 \pm 9.8$ & 11.8 \\
$\mathrm{SiO}_{2}$ & $6.2 \pm 0.4$ & 523.4 & $398.1 \pm 24.8$ & 5.0 \\
$\mathrm{NiO}$ & $5.3 \pm 0.4$ & 91.8 & $100.8 \pm 38.5$ & 32.7 \\
$\mathrm{CO}_{3} \mathrm{O}_{4}$ & $18.4 \pm 0.8$ & 35.8 & $148.2 \pm 95.5$ & 83.8 \\
$\mathrm{Cr}_{2} \mathrm{O}_{3}$ & $205 \pm 20.7$ & 74.42 & $195.3 \pm 101.4$ & 40.3 \\
$\mathrm{ZnO}$ & $10.7 \pm 0.7$ & 48.2 & $492.8 \pm 25.2$ & 62.0 \\
$\mathrm{CuO}$ & $23.1 \pm 1.0$ & 29 & $95.6 \pm 1.6$ & 103 \\
\hline
\end{tabular}

${ }^{a}$ NPs were provided by Nanostructural and Amorphous Materials Inc. (Houston, TX, USA) except for CB (Evonik Degussa GmbH, Frankfurt, Germany), ZnO (NanoScale Corporation, Manhattan, KS, USA), and CuO (Sigma-Aldrich).

${ }^{b}$ Primary particle sizes were measured by a transmission electron microscopy.

'Surface area was measured by BET (Brunauer-Emmett-Teller) method.
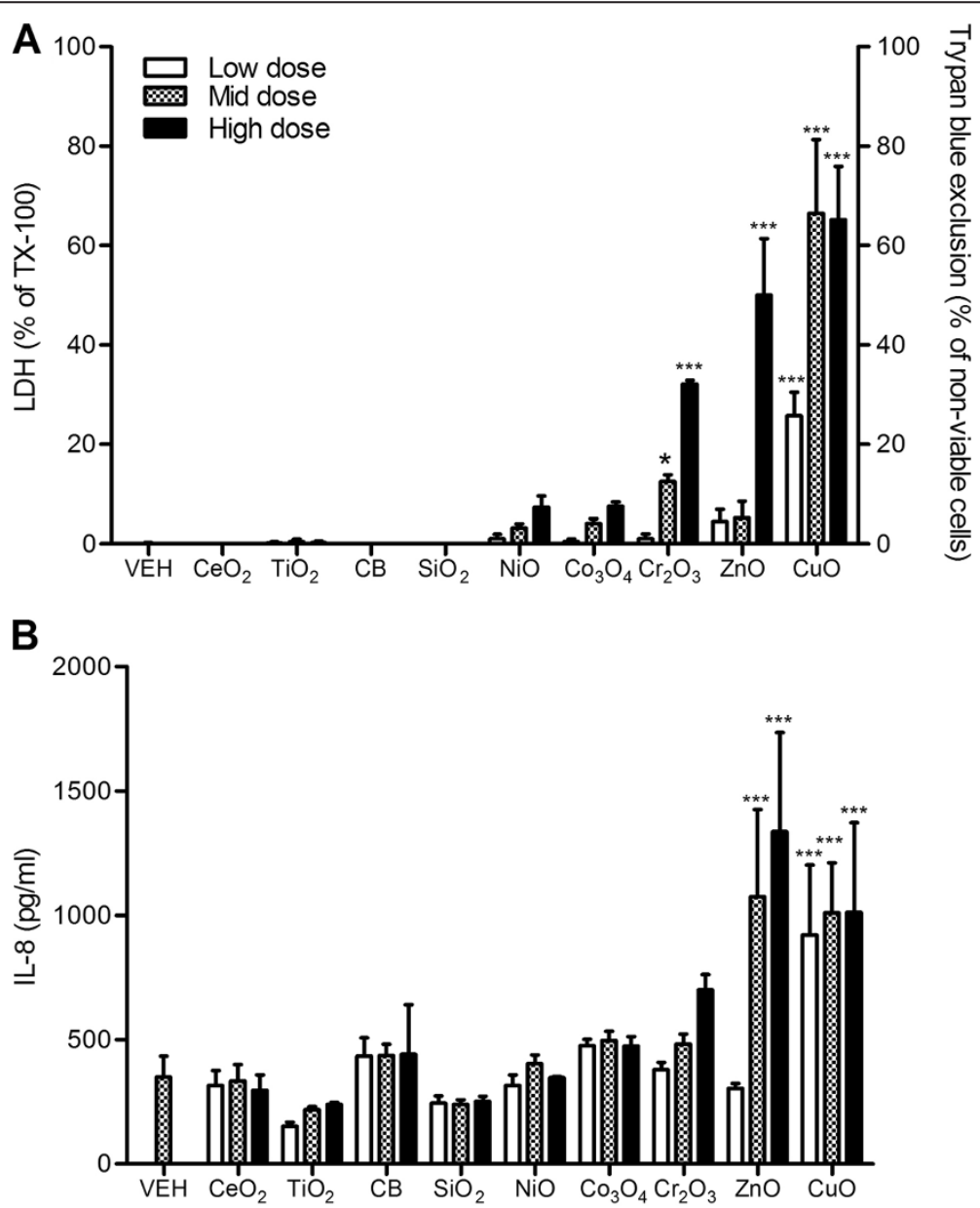

Figure 1 Cytotoxicity and IL-8 expression of A549 cells after exposure to NPs for $\mathbf{2 4}$ h. (A) Cytotoxicity was measured by trypan blue exclusion for $\mathrm{ZnO}$ and $\mathrm{CuO} N \mathrm{NP}$ whilst others were measured by LDH. (B) Levels of IL-8 of A549 cells at $24 \mathrm{~h}$ following treatment. Note that the surface area doses were 30,100, and $300 \mathrm{~cm}^{2} / \mathrm{mL}$ except for $\mathrm{ZnO}$ and CuO NP which were 3, 10, and $30 \mathrm{~cm} / 2 \mathrm{~mL}$. Values are mean \pm SD from minimum four independent experiments. Significance versus vehicle control (VEH): ${ }^{*} p<0.05,{ }^{* * *} p<0.001$. 

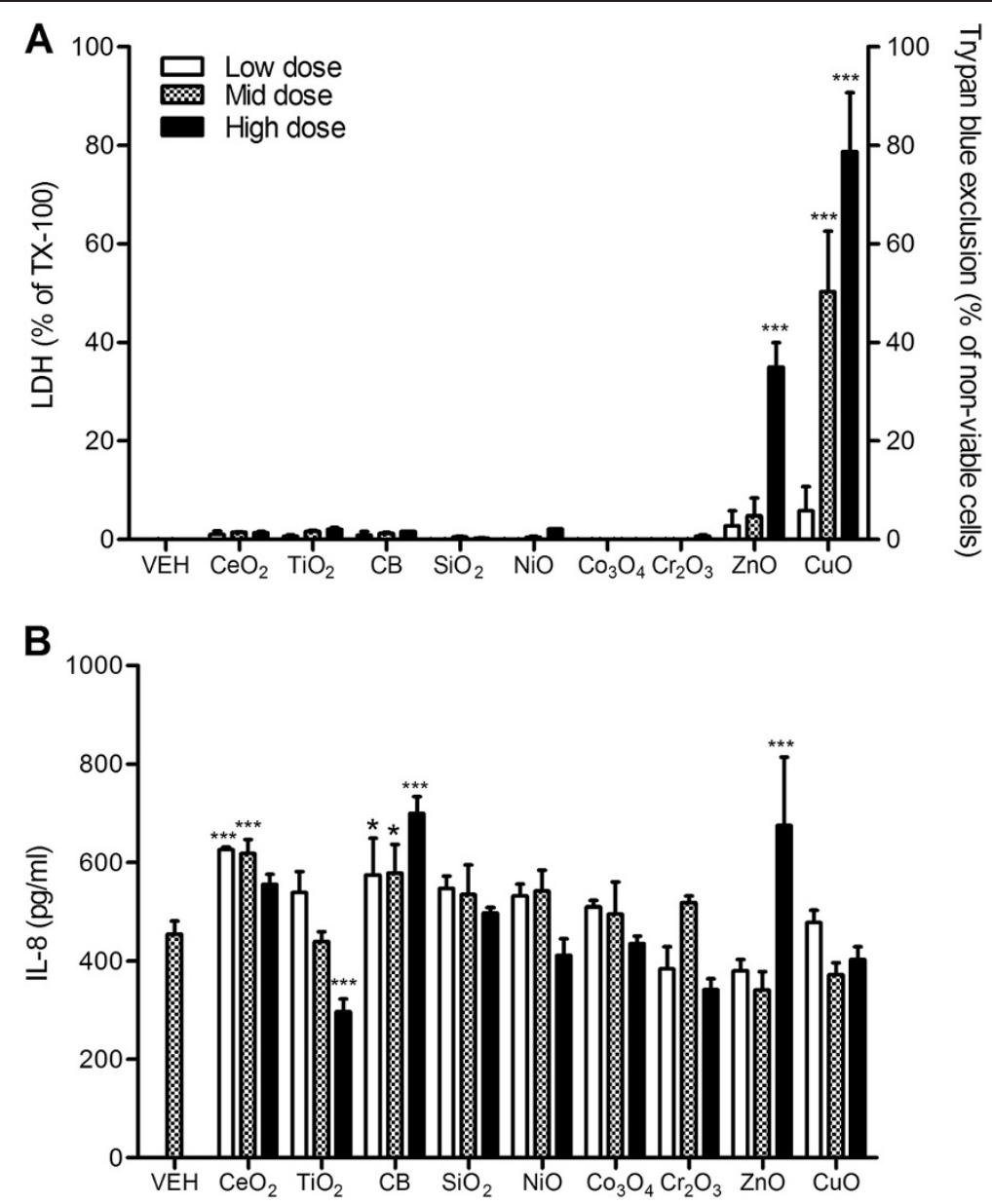

Figure 2 Cytotoxicity and IL-8 expression of 16-HBE cells after exposure to NPs for $\mathbf{2 4}$ h. (A) Cytotoxicity was measured by trypan blue exclusion for $\mathrm{ZnO}$ and CuO NP whilst others were measured by LDH. (B) Levels of IL-8 of 16-HBE cells at $24 \mathrm{~h}$ following treatment. Note that the surface area doses were 30,100, and $300 \mathrm{~cm}^{2} / \mathrm{mL}$ except for $\mathrm{ZnO}$ and CuO NP which were 3, 10, and $30 \mathrm{~cm} / \mathrm{mL}$. Values are mean \pm SD from minimum four independent experiments. Significance versus vehicle control (VEH): ${ }^{*} p<0.05,{ }^{* * *} p<0.001$.

$\mathrm{NP}$ effect was produced at $300 \mathrm{~cm}^{2} / \mathrm{mL}$ whilst the dose of $10 \mathrm{~cm}^{2} / \mathrm{mL}$ of $\mathrm{CuO} \mathrm{NP}$ was approximately equipotent for IL-1 $\beta$.

\section{Peripheral blood monocyte-derived macrophages (PBMDM)}

PBMDM were differentiated from the peripheral blood mononuclear cells (PBMC) by culturing for 5 days. All NPs excluding $\mathrm{CeO}_{2}, \mathrm{TiO}_{2}$, and $\mathrm{SiO}_{2} \mathrm{NP}$ showed significant cytotoxicity compared to vehicle control (Figure 5A). The levels of IL-1 $\beta$ were significantly increased by $\mathrm{TiO}_{2}, \mathrm{CB}, \mathrm{NiO}, \mathrm{Cr}_{2} \mathrm{O}_{3}$, and $\mathrm{ZnO} \mathrm{NP}$ (Figure 5B). The levels of TNF- $\alpha$ were significantly increased by $\mathrm{TiO}_{2}$ and $\mathrm{ZnO}$ NP whilst other NPs were comparable with vehicle control (Figure 5C).

\section{Differentiated THP-1 cells}

Differentiated THP-1 cells by treatment with phorbol myristate acetate (PMA) showed much greater sensitivity compared to monocytic THP-1 cells. $\mathrm{CeO}_{2}, \mathrm{TiO}_{2}, \mathrm{NiO}$, $\mathrm{Cr}_{2} \mathrm{O}_{3}, \mathrm{ZnO}$, and $\mathrm{CuO}$ NP showed significantly increased cytotoxicity compared to vehicle control (Figure 6A). The use of differential doses, however, again revealed that $\mathrm{ZnO}$ and $\mathrm{CuO} \mathrm{NP}$ were an order of magnitude or more cytotoxic than the others. Levels of IL- $1 \beta$ were increased in $\mathrm{CeO}_{2}$ and $\mathrm{TiO}_{2}$ NP-treated cells and showed modest increases with $\mathrm{CB}, \mathrm{SiO}_{2}, \mathrm{Co}_{3} \mathrm{O}_{4}$, and $\mathrm{Cr}_{2} \mathrm{O}_{3} \mathrm{NP}$ (Figure 6B). In contrast, the levels of TNF- $\alpha$ showed marked increases on treatment with $\mathrm{CeO}_{2}$ and $\mathrm{NiO} \mathrm{NP}$ and slight increases by $\mathrm{TiO}_{2}$ and $\mathrm{Cr}_{2} \mathrm{O}_{3} \mathrm{NP}$ (Figure 6C). Treatment of cytochalasin $\mathrm{D}$, a well characterized inhibitor of phagocytosis, dramatically inhibited the expression of IL-1 $\beta$ showing around $1 / 15$ and $1 / 7$ reductions for $\mathrm{CeO}_{2}$ and $\mathrm{TiO}_{2} \mathrm{NP}$ compared to the same treatment without cytochalasin D (Figures 6D).

\section{Combined culture}

The levels of IL-8 in the conditioned media from THP-1 cells before addition of A549 cells were significantly 

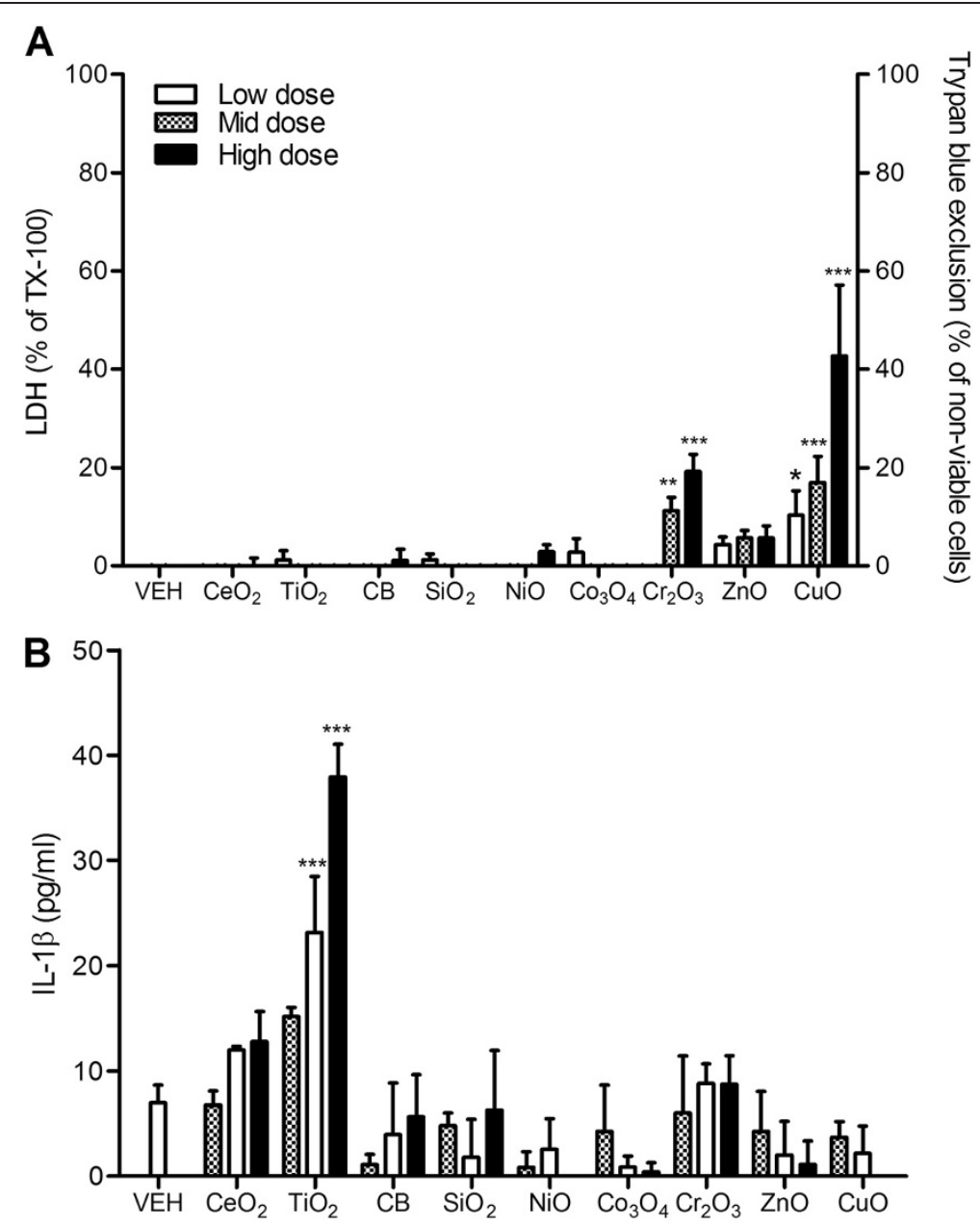

Figure 3 Cytotoxicity and IL-1 $\beta$ expression of monocytic THP-1 cells after exposure to NPs for $\mathbf{2 4}$ h. (A) Cytotoxicity was measured by trypan blue exclusion for $\mathrm{ZnO}$ and CuO NP whilst others were measured by LDH. (B) Levels of IL-1 $\beta$ of monocytic THP-1 cells at $24 \mathrm{~h}$ following treatment. Note that the surface area doses were 30,100 , and $300 \mathrm{~cm}^{2} / \mathrm{mL}$ except for $\mathrm{ZnO}$ and CuO NP which were 3,10, and $30 \mathrm{~cm} / \mathrm{mL}$. Values are mean \pm SD from minimum four independent experiments. Significance versus vehicle control (VEH): ${ }^{*} p<0.05,{ }^{* *} p<0.01,{ }^{* * *} p<0.001$.

increased by $\mathrm{TiO}_{2}, \mathrm{ZnO}$, and $\mathrm{CuO} \mathrm{NP}$ treatment (Figure 7A). Addition of NP-free conditioned media to A549 cells produced a marked increase in IL-8 levels in the $\mathrm{CeO}_{2}, \mathrm{TiO}_{2}, \mathrm{Cr}_{2} \mathrm{O}_{3}, \mathrm{ZnO}$, and $\mathrm{CuO} \mathrm{NP}$ treatment groups (Figure $7 \mathrm{~B}$ ). Compared with single treatment to A549 cells presented in Figure 1B, conditioned medium produced more sensitive and higher responses for the IL-8 production.

\section{Haemolysis assay}

$\mathrm{CeO}_{2}, \mathrm{NiO}, \mathrm{Co}_{3} \mathrm{O}_{4}$, and $\mathrm{CuO} \mathrm{NP}$ showed significant haemolytic potential compared to vehicle control (Figure 8) and all were tested at equal surface area dose. However, it was notable that there was a real difference in potency with $\mathrm{NiO} \mathrm{NP}$ being at least 2 times more potent than the others in all treatment doses.

\section{Correlation of in vitro assays with in vivo acute lung inflammogenicity}

Table 2 summarise the number of total granulocytes in the bronchoalveolar lavage fluid in the lungs of rats treated at $150 \mathrm{~cm}^{2} /$ rat after $24 \mathrm{~h}$ of instillation. Table 3 summarise the utility of the various in vitro assays for predicting lung inflammogenicity of NP panel. Because the gold standard for comparison between lung inflammation and several in vitro assays was dosed at equal surface area dose, we took the $30 \mathrm{~cm}^{2} / \mathrm{mL}$ dose as the measure of a significant effect. Cytotoxicity in differentiated PBMC (PBMDM) showed the best accuracy - 89\% (8/9) accuracy, 11\% (1/9) false negativity, and $0 \%(0 / 9)$ false positivity to predict acute lung inflammogenicity. The second best assay was cytotoxicity using primary cultured alveolar macrophages which showed 78\% (7/9) accuracy, 11\% (1/9) false negativity, and $11 \%(1 / 9)$ false positivity. Data from other cell 

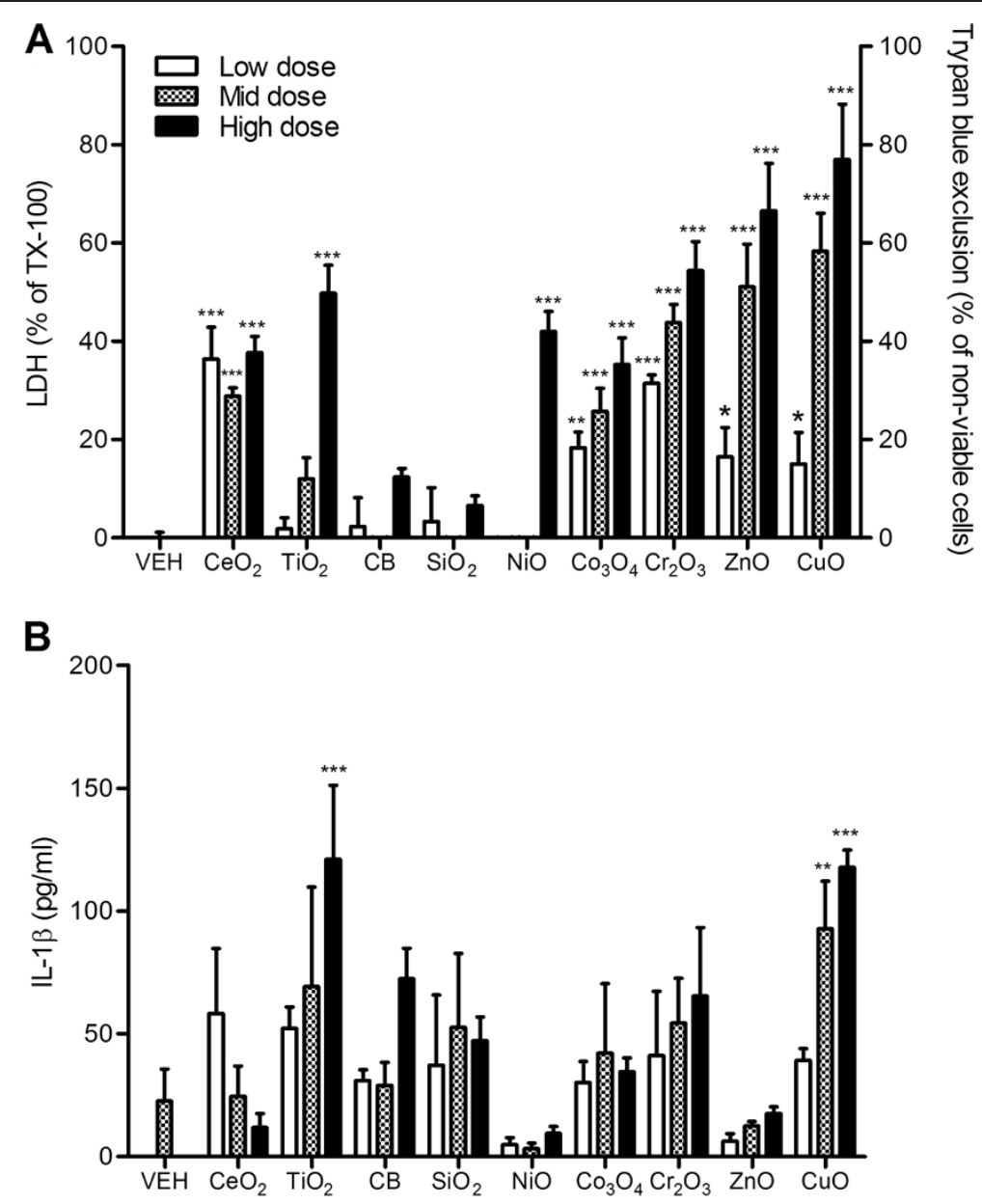

Figure 4 Cytotoxicity and IL-1 $\beta$ expression of primary cultured alveolar macrophages after exposure to NPs for $24 \mathrm{~h}$. (A) Cytotoxicity was measured by trypan blue exclusion for $\mathrm{ZnO}$ and $\mathrm{CuO}$ NP whilst others were measured by LDH. (B) Levels of IL-1 $\beta$ of primary cultured alveolar macrophages at $24 \mathrm{~h}$ following treatment. Note that the surface area doses were 30, 100, and $300 \mathrm{~cm} / \mathrm{mL}$ except for ZnO and CuO NP which were 3,10 , and $30 \mathrm{~cm}^{2} / \mathrm{mL}$. Values are mean $\pm \mathrm{SD}$ from minimum four independent experiments. Significance versus vehicle control (VEH): ${ }^{*} p<0.05,{ }^{* *} p<0.01, \quad{ }^{* * *} p<0.001$.

types or pro-inflammatory cytokine assays using PBMDM and alveolar macrophages showed a poor correlation with in vivo lung inflammogenicity. In contrast, the in vitro assay data at any dose that have statistical significance showed that the haemolysis assay was the most accurate (Table 4). Table 3 can also suggest the mechanisms of action of various metal oxide NPs. Among the NP that caused inflammation, $\mathrm{CeO}_{2}$ NP had a range of activities causing IL-8 release from 16-HBE, toxicity to alveolar macrophages, and TNF- $\alpha$ release from THP- 1 cells. NiO NP show no persuasive effects whilst $\mathrm{Co}_{3} \mathrm{O}_{4} \mathrm{NP}$ seemed to kill macrophages without stimulating them. $\mathrm{TiO}_{2}, \mathrm{CB}, \mathrm{SiO}_{2}$, and $\mathrm{Cr}_{2} \mathrm{O}_{3}$ NP showed no convincing effects whilst $\mathrm{ZnO}$ and $\mathrm{CuO}$ NP caused significant changes in most of assays.

\section{Discussion}

Cell-based in vitro toxicity testing is very important not only for evaluation of mechanism of action but also for alternative testing methods to replace animal experimentation [14]. In nanotoxicology, in vitro toxicity testing for NPs has a high priority and indeed most of the studies have been conducted in vitro [15]. However, the responses to NPs are known to be very variable depending on cell type because of the diverse physiological functions of cells and the heterogeneous physicochemical properties of NPs [8]. In this study, we used 9 predominantly metal oxide NPs and tested cytotoxicity and pro-inflammatory cytokine expression using 8 different cell-based toxicity testing models relevant to the lung. The efficacy of in vitro testing methods was evaluated against the potential of the panel to cause acute lung inflammation in rats using data that we published previously $[16,17]$. All NPs used in in vivo and in vitro study were exactly same batch and both studies were performed contemporaneously.

Differentiated THP-1 cells by PMA treatment were considerably more sensitive to NPs with respect to both 


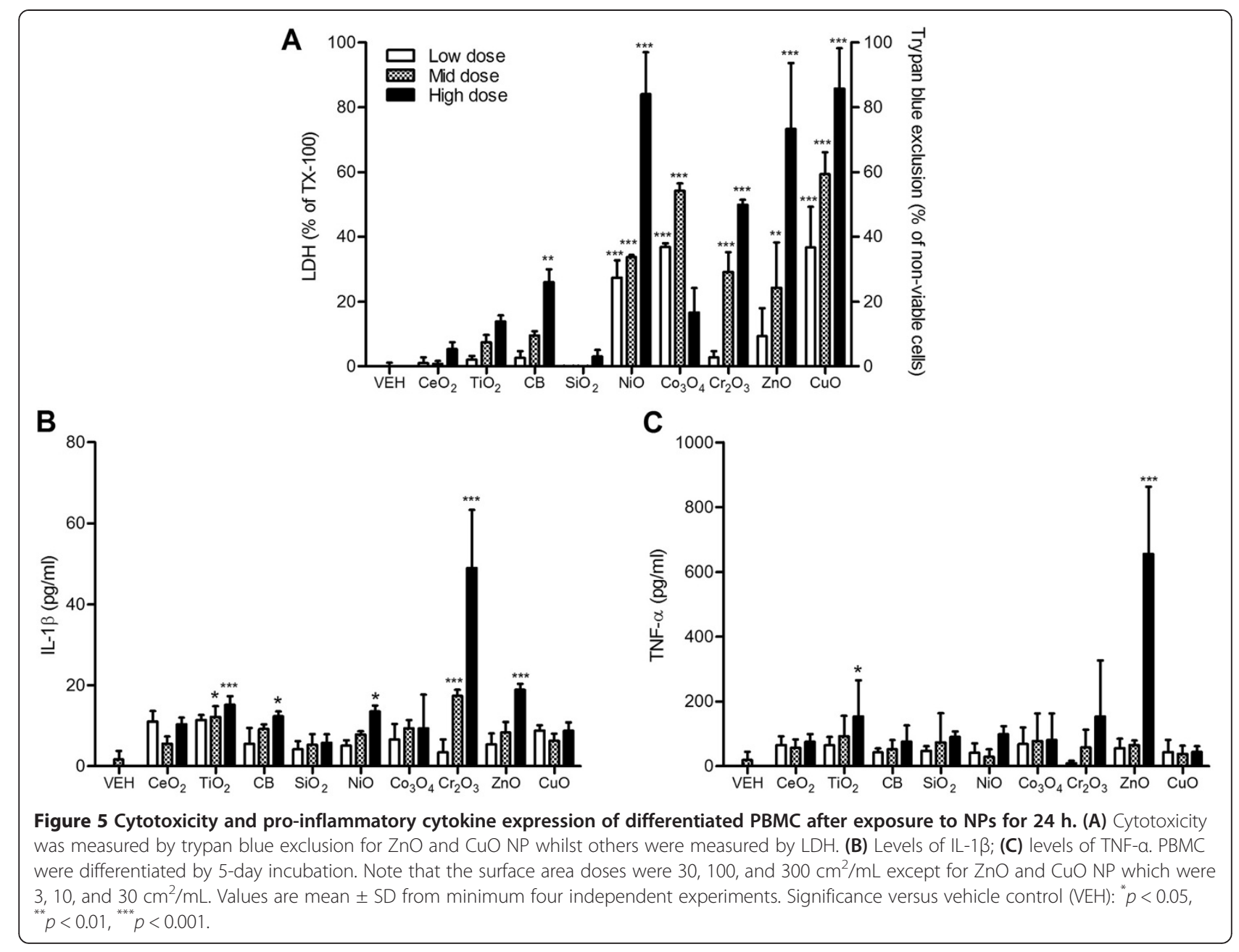

cytotoxicity and cytokine expression, compared to undifferentiated THP- 1 cells. The pattern of IL- $1 \beta$ expression was slightly different from that of TNF- $\alpha$. For example, $\mathrm{TiO}_{2}$ NP induced the greatest response with respect to IL-1 $\beta$ but only a slight increase in TNF- $\alpha$; NiO NP on the other hand did not increase IL- $1 \beta$ but caused a substantial increase in TNF- $\alpha$ levels. This might mean that each metal oxide triggers inflammation by different pathways, possibly resulting in different modes of inflammation depending on their physicochemical properties [16]. Interestingly $\mathrm{ZnO}$ and $\mathrm{CuO} \mathrm{NP}$ failed to induce any cytokines response but were found to be highly cytotoxic. The cytotoxicity of $\mathrm{ZnO}$ and $\mathrm{CuO} \mathrm{NP}$ is likely due to their water soluble ions [18]. In addition to this, accelerated dissolution of $\mathrm{ZnO}$ [19] and $\mathrm{CuO} \mathrm{NP}$ [20] inside of the acidic lysosomal fluid might be more effective in macrophages compared to monocytic cells. Several NPs such as $\mathrm{SiO}_{2}$ and $\mathrm{TiO}_{2}$ NP were recently known to cause release of IL- $1 \beta$ by activating NLR pyrin domain containing 3 (Nlrp3) inflammasome [21,22]. However, ZnO NP did not activate the Nlrp3 inflammasome and failed to stimulate release of IL- $1 \beta$ and the mechanism of inflammasome activation was poorly understood [21]. The pH-dependent dissolution of $\mathrm{ZnO}$ and $\mathrm{CuO}$ NP inside phagolysosomes causes the NPs to lose the physico-chemical properties that might influence the phagocytosis-related inflammasome activation and pro-inflammatory cytokine expression. The expression of IL- $1 \beta$ by NPs was markedly reduced by inhibition of phagocytosis using cytochalasin D. Therefore, phagocytosis is an important mechanism of producing IL- $1 \beta$ by activation of inflammasome. TNF- $\alpha$ is another important pro-inflammatory cytokine driving inflammation in the lung and $\mathrm{CeO}_{2}$ and $\mathrm{NiO} \mathrm{NP}$, the two NPs highly responsive to TNF- $\alpha$, was consistent with the inflammogenicity in the lung [16].

Treatment of A549 cells with NP-free conditioned medium from THP-1 cells (combined culture) showed much greater response in IL-8 production compared to the direct particle exposure. The increases of IL-8 in A549 cells caused by $\mathrm{CeO}_{2}, \mathrm{TiO}_{2}$, and $\mathrm{Cr}_{2} \mathrm{O}_{3} \mathrm{NP}$ in the combined culture were mainly due to the TNF- $\alpha$ and IL$1 \beta$ released by THP- 1 cells. The increased IL- 8 levels released by $\mathrm{A} 549$ cells on treatment with $\mathrm{ZnO}$ and $\mathrm{CuO}$ 


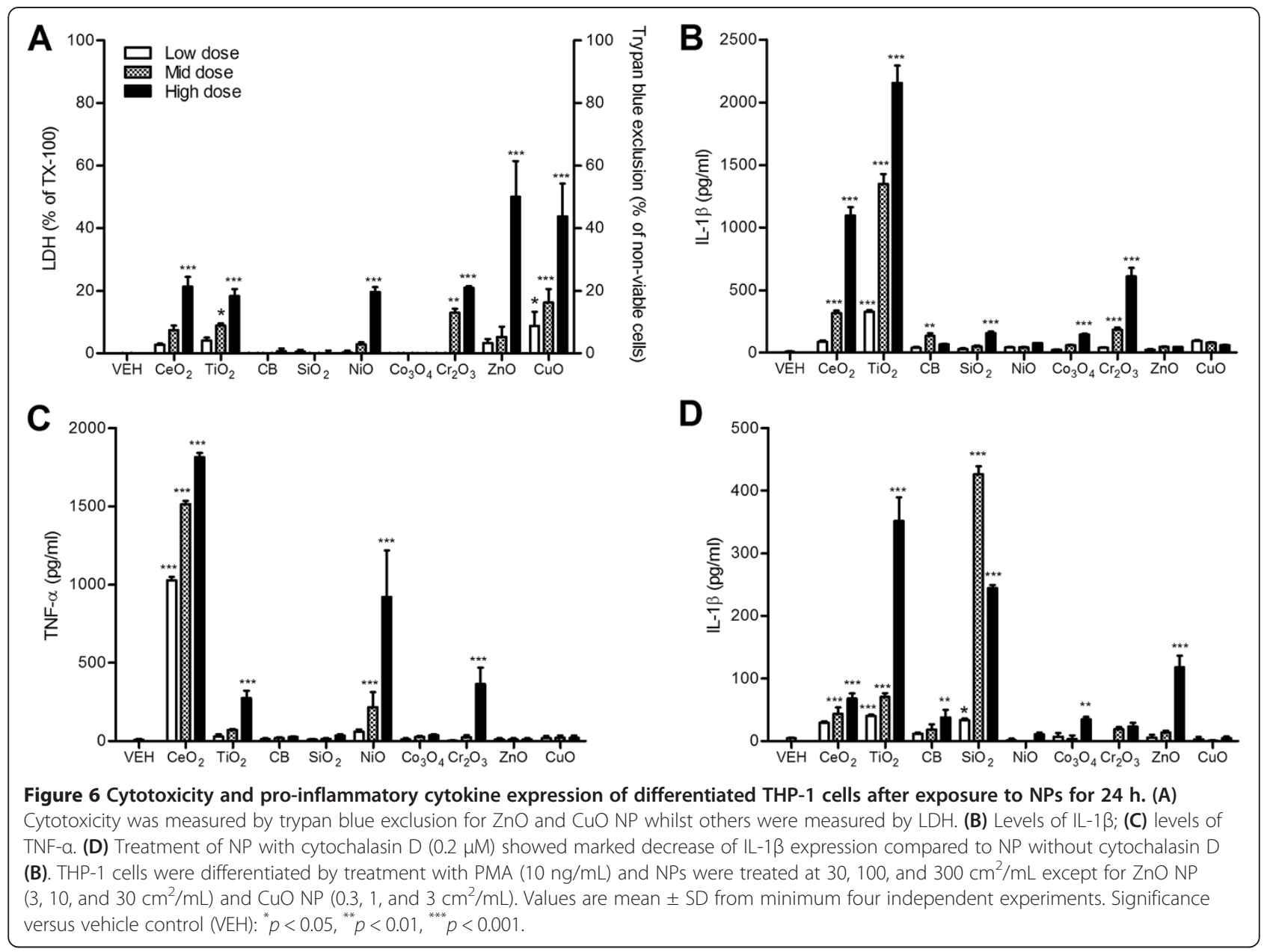

NP may be due to IL- 8 produced by THP-1 cells and the release of water soluble metal ions by THP-1 cells. Although the combined culture is a good method to evaluate the action of pro-inflammatory cytokines released from one cell type on another cell type [23-25], the toxic ions released from soluble NPs also should be carefully taken into account in this assay [18].

In our previous studies we reported that the $\mathrm{CeO}_{2}$, $\mathrm{NiO}$, and $\mathrm{Co}_{3} \mathrm{O}_{4}$ NP had surface charge as their biologically effective dose (BED) whilst $\mathrm{ZnO}$ and $\mathrm{CuO} \mathrm{NP}$ had soluble toxic ions as their BED [26,27]. When NPs were inhaled, NPs gain a protein corona and so the surface charge might be blocked and the toxicities mitigated [28]. However, the protein corona may have little role with NPs which dissolve in acidic conditions [26]. This might be the reason why the most of in vitro assay data of $\mathrm{ZnO}$ and $\mathrm{CuO} \mathrm{NP}$ are consistent with the lung inflammation data.

When NPs were dosed at $30 \mathrm{~cm}^{2} / \mathrm{mL}$ which is the only overlapping dose between NPs, the cytotoxicity in differentiated peripheral blood mononuclear cells was the most consistent with the lung inflammation data. In addition, haemolysis assay showed the best accuracy (100\%) when haemolysis at any dose was taken to represent positivity in the assay. The haemolysis assay has been proposed as a good model for prediction of in vivo lung inflammation [29]. However, haemolysis assay is not applicable to NPs like $\mathrm{ZnO}$ which have high binding affinity with haemoglobin and small-sized well-dispersed NPs which need ultracentrifugation to get rid of NPs. In addition, the haemolysis assay should use protein-free saline as a vehicle because protein corona protects the surface reactivity in cell culture condition [26,30,31]. Although both cell culture and in vivo condition can produce a corona, the surface reactivity might be unmasked more fully in vivo [26] but unmasking might be variable in in vitro depending on the cell types and culture conditions. This might be due to the differences in the enzymatic activity inside of phagolysosomes between each model [32] and synergistic effect by crosstalking between each cell type. Among 8 different in vitro systems, alveolar macrophages, differentiated PBMC, and red blood cells were better for prediction of in vivo lung inflammogenicity of NPs than other 

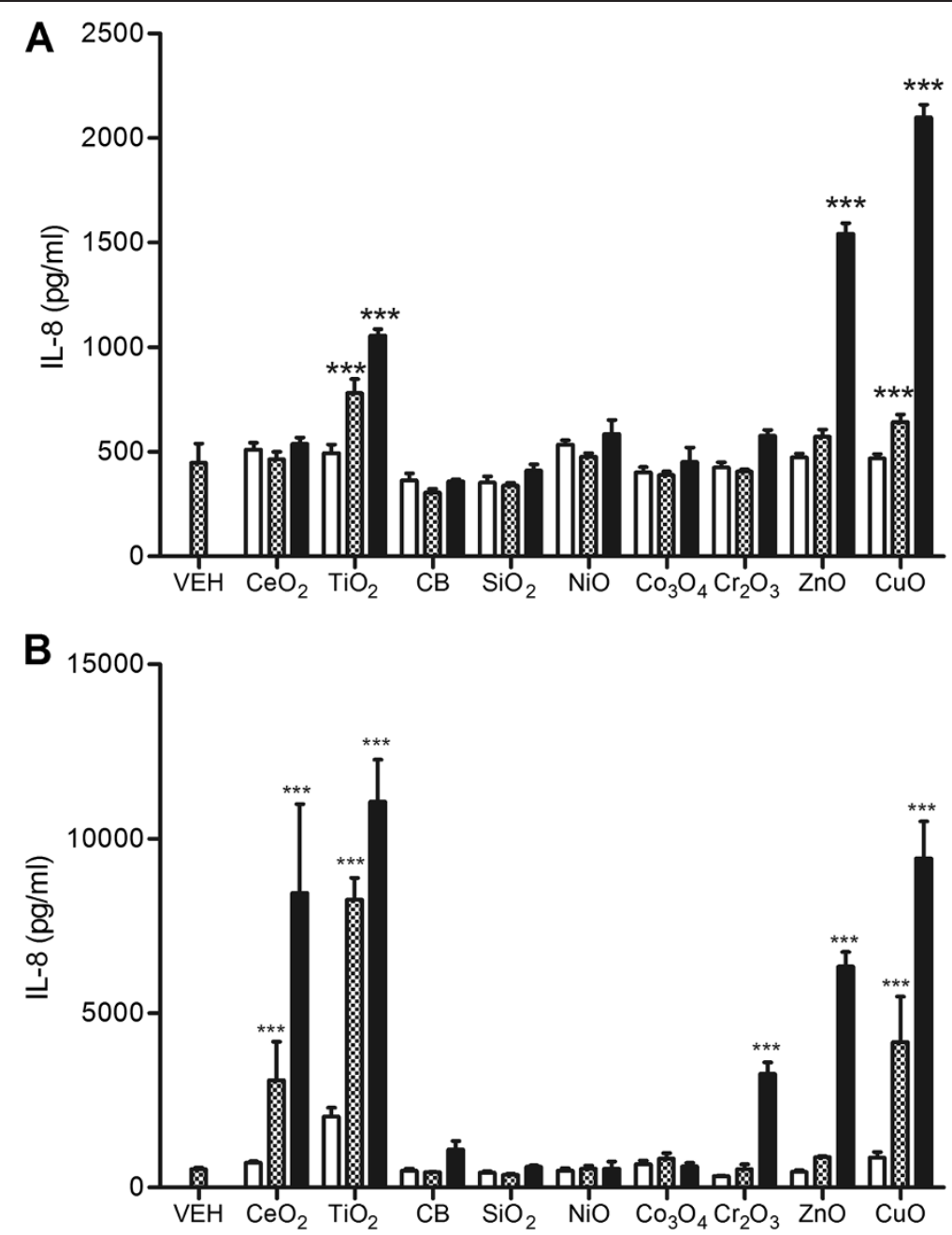

Figure 7 IL-8 expression by NP-conditioned media. A549 cells were exposed to conditioned media from NP-exposed differentiated THP-1 cells for $4 \mathrm{~h}$. THP-1 cells were differentiated by treatment for PMA $(10 \mathrm{ng} / \mathrm{mL})$ and NPs were treated at surface area doses of 30, 100, and $300 \mathrm{~cm}^{2} / \mathrm{mL}$ except for ZnO NP $\left(3,10\right.$, and $\left.30 \mathrm{~cm}^{2} / \mathrm{mL}\right)$ and CuO NP $\left(0.3,1\right.$, and $\left.3 \mathrm{~cm}^{2} / \mathrm{mL}\right)$. (A) The levels of IL-8 in the conditioned $\mathrm{media}$ from THP-1 cells before addition of A549 cells. (B) The levels of IL-8 after addition of NP-free conditioned media to A549 cells. Values are mean \pm SD from minimum four independent experiments. Significance versus vehicle control (VEH): ${ }^{* * *} p<0.001$.

systems. As a minimum set of in vitro endpoints, cytotoxicity assay can be suggested for better parameters for correlation with in vivo lung inflammogenicity than proinflammatory cytokine assay.

\section{Conclusions}

Based on the toxicity mechanisms of NPs, two different approaches can be applied for prediction of in vivo lung inflammogenicity. Most in vitro assays may detect toxic or inflammogenic potential of NPs if the NPs act via soluble ions (i.e., $\mathrm{ZnO}$ and $\mathrm{CuO} \mathrm{NP}$ ). However, in vitro assays appear not to be good at detecting metal oxide NPs that act via surface charge as their mechanism of toxicity, with the key exception of haemolysis.

\section{Materials and methods}

\section{Nanoparticle and characterization}

A total of 9 different predominantly metal oxide NPs $\left[\mathrm{CeO}_{2}, \mathrm{TiO}_{2}\right.$ (rutile form), carbon black (CB), $\mathrm{SiO}_{2}, \mathrm{NiO}$, $\mathrm{Co}_{3} \mathrm{O}_{4}, \mathrm{Cr}_{2} \mathrm{O}_{3}, \mathrm{CuO}$, and $\mathrm{ZnO}$ ] were purchased from commercial sources (Table 1 ). The primary size of NP was measured by transmission electron microscopy (TEM) (JEM-1200EX II, JEOL, Tokyo, Japan). The surface area (BET, Brunauer-Emmett-Teller) of NPs was measured using a Micromeritics TriStar 3000 (Bedfordshire, UK). Agglomeration status of NP in PBS with/ without dispersion medium (fetal bovine serum, FBS) was measured by dynamic light scattering (Brookhaven 90 plus; Holtsville, NY, USA). Endotoxin levels in NP suspensions were evaluated by an endpoint chromogenic 


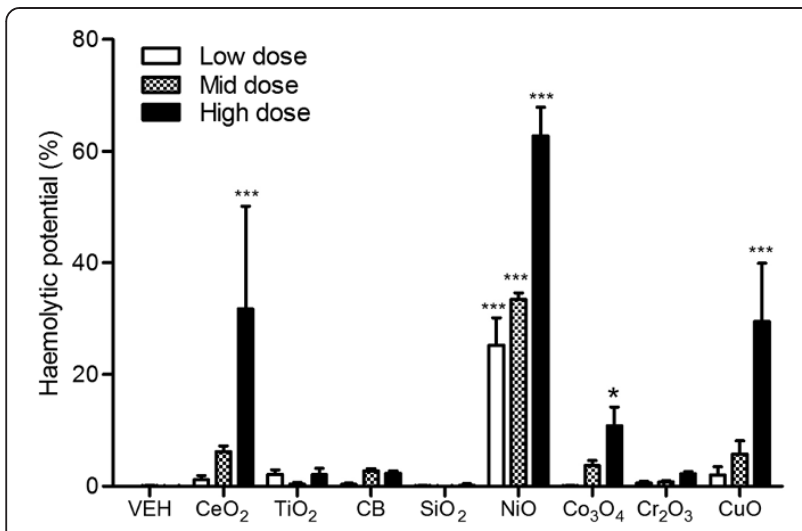

Figure 8 Haemolysis assay of NP. NPs were treated at surface area doses of 30,100 , and $300 \mathrm{~cm}^{2} / \mathrm{mL}$. Values are mean \pm SD from minimum four independent experiments. Significance versus vehicle control (VEH): ${ }^{*} p<0.05,{ }^{* * *} p<0.001$.

Limulus Amebocyte Lysate (LAL) assay (Cambrex, MD, USA). The detection limit of LAL kit was $0.1-1.0 \mathrm{EU} / \mathrm{ml}$.

\section{Rationale for dose selection}

All experiments were performed using surface area as a dose metric because surface area is considered to be the most appropriate metric for assessing NP toxicity in vivo and in vitro [12]. For in vitro assays, we performed preliminary dose-ranging studies for all NPs from 0.1 to $300 \mathrm{~cm}^{2} / \mathrm{mL}$. Based on their cytotoxicity, all NPs were used at doses of 30,100, and $300 \mathrm{~cm}^{2} / \mathrm{mL}$, except for $\mathrm{CuO}$ and $\mathrm{ZnO}$ NPs, which were treated at 3, 10, $30 \mathrm{~cm}^{2} /$ $\mathrm{mL}$ because of their greater toxicity. In our previous studies, NPs were intratracheally instilled into the lungs of female Wistar rats at 50,150, $250 \mathrm{~cm}^{2} / \mathrm{mL}[16,17,29]$. As a result, $\mathrm{CeO}_{2}$ and $\mathrm{NiO} \mathrm{NP}$ were inflammogenic from $150 \mathrm{~cm}^{2} / \mathrm{mL}$ and $\mathrm{ZnO}$ and $\mathrm{CuO} \mathrm{NP}$ were inflammogenic from $50 \mathrm{~cm}^{2} / \mathrm{mL}$. Treatment of $\mathrm{TiO}_{2}, \mathrm{CB}, \mathrm{SiO}_{2}$

Table 2 The number of total granulocytes in the BAL at $24 \mathrm{~h}$ after instillation of NPs into rats

\begin{tabular}{lll}
\hline $\mathbf{N P}$ & Total cells $\left(\times 1 \mathbf{0}^{\mathbf{5}}\right)$ & Granulocytes $\left(\times 1 \mathbf{0}^{5}\right)$ \\
\hline Vehicle control & $7.5 \pm 3.1$ & $0.2 \pm 0.1$ \\
$\mathrm{CeO}_{2}$ & $42.3 \pm 25.9^{* *}$ & $37.1 \pm 23.2^{* * *}$ \\
$\mathrm{TiO}_{2}-$ rutile & $7.6 \pm 2.6$ & $1.5 \pm 1.8$ \\
$\mathrm{CB}$ & $13.1 \pm 4.4$ & $8.0 \pm 3.3$ \\
$\mathrm{SiO}_{2}$ & $6.1 \pm 1.0$ & $0.5 \pm 0.7$ \\
$\mathrm{NiO}^{*}$ & $45.5 \pm 16.8^{* *}$ & $35.0 \pm 17.0^{* * *}$ \\
$\mathrm{CO}_{3} \mathrm{O}_{4}$ & $104.4 \pm 12.4^{* * *}$ & $93.8 \pm 11.3^{* * *}$ \\
$\mathrm{Cr}_{2} \mathrm{O}_{3}$ & $39.9 \pm 12.1^{* *}$ & $1.7 \pm 1.6$ \\
$\mathrm{ZnO}$ & $16.0 \pm 4.1$ & $13.2 \pm 5.0^{*}$ \\
$\mathrm{CuO}^{*}$ & $40.5 \pm 3.6^{* *}$ & $36.9 \pm 3.8^{* * *}$ \\
\hline
\end{tabular}

The acute lung inflammogenicity data were used from our previously published data $[16,17]$.

Significance versus vehicle control: ${ }^{*} p<0.05,{ }^{* *} p<0.01,{ }^{* * *} p<0.001$. did not show any significant inflammation. Therefore, we selected $150 \mathrm{~cm}^{2} / \mathrm{mL}$ for acute lung inflammation because NiO NP is well known as toxic particles in human cell lines [33] and in rats [34]. To evaluate the correlation of in vitro data against in vivo data, the dose for in vivo was fixed at $150 \mathrm{~cm}^{2} / \mathrm{mL}$ and compared with in vitro data at various doses.

\section{Dispersion of NPs}

Because NPs showed some agglomerates which are not readily dispersed without any stresses (i.e., sonication) in PBS, NPs were dispersed with 5\% FBS which provide a protein corona on the surface of particles as previously described method [16].

\section{Cell culture}

When NPs are inhaled, they immediately interact with epithelial cells and then alveolar macrophages. Red blood cells have been used in particle toxicology studies to determine direct membranolytic effects of particle surfaces and we emphasise that interactions with red blood cells are not part of the pathophysiological mechanism by which NP act. Therefore we selected alveolar epithelial cells - A549 cells, bronchial epithelial cells - 16-HBE cells, monocytic/macrophage cells THP-1 cells, human peripheral blood mononuclear cells (PBMC), and rat alveolar macrophages and human red blood cells. A549 cells were obtained from the European Collection of Animal Cell Cultures and THP-1 cells were purchased from American Type Culture Collection (ATCC). 16-HBE cells originated from Dr. Gruenert of the University of California, San Francisco, USA [35]. Rat alveolar macrophages underwent primary culture following whole lung lavage in 7-week old healthy female Wistar rats. Human peripheral whole blood was collected from healthy consenting volunteers (University of Edinburgh) and PBMC were then isolated from buffy coats according to the previously described method [36]. A549 cells and 16-HBE cells were cultured in DMEM medium containing 5\% FBS and THP-1 cells, PBMC, and rat alveolar macrophages were cultured in RPMI1640 medium containing 10\% FBS. Cells were cultured at $37^{\circ} \mathrm{C}$ with $5 \% \mathrm{CO}_{2}, 2 \mathrm{mM}$ L-glutamine (Life Technologies, Paisley, UK), $100 \mathrm{IU} / \mathrm{mL}$ penicillin, and $100 \mathrm{U} /$ $\mathrm{mL}$ streptomycin (Life Technologies). The number of cells for seeding to 6 -well plate was $2 \times 10^{5}$ cells $/ \mathrm{mL}$ for A549 cells and 16-HBE cells and $1 \times 10^{6}$ cells $/ \mathrm{mL}$ for monocytic/macrophage cells. The monocytic THP-1 cells were differentiated to macrophages with $10 \mathrm{ng} / \mathrm{mL}$ of phorbol myristate acetate (PMA; Sigma-Aldrich, Gillingham, Dorset, UK) for 2 days and Peripheral blood monocyte-derived macrophages (PBMDM) were differentiated from PBMC by culturing for 5 days. After 
Table 3 Comparison of in vivo lung inflammation data with in vitro assay data at the same surface area dose $(30 \mathrm{~cm} / \mathrm{mL})$ unless otherwise stated

\begin{tabular}{|c|c|c|c|c|c|c|c|c|c|c|c|c|c|c|c|c|c|}
\hline & \multirow{2}{*}{$\frac{\text { Rat }\left(150 \mathrm{~cm}^{2} / \mathrm{rat}\right)}{\text { granulocytes }}$} & \multicolumn{2}{|c|}{ A549 } & \multicolumn{2}{|c|}{ 16-HBE } & \multicolumn{2}{|c|}{ THP-1 } & \multicolumn{2}{|c|}{ Alveolar mac } & \multicolumn{3}{|c|}{ Differentiated PBMC } & \multicolumn{3}{|c|}{ DifferentiatedTHP-1 $^{\mathrm{a}}$} & \multirow{2}{*}{$\frac{\text { Combined (A549+ THP-1) }}{\text { IL-8 }}$} & \multirow{2}{*}{$\frac{\text { Haemolysis }}{\% \text { haemolysis }}$} \\
\hline & & cytotox $^{b}$ & IL-8 & cytotox & IL-8 & cytotox & IL-1 $\beta$ & cytotox & IL-1 $\beta$ & cytotox & IL-1 $\beta$ & $\overline{\text { TNF- } a}$ & cytotox & IL-1 $\beta$ & $\overline{\text { TNF-a }}$ & & \\
\hline $\mathrm{CeO}_{2}$ & + & - & - & - & + & - & - & + & - & - & - & - & - & - & + & - & - \\
\hline $\mathrm{TiO}_{2}$-rutile & - & - & - & - & - & - & - & - & - & - & - & - & - & + & - & - & - \\
\hline$C B$ & - & - & - & - & + & - & - & - & - & - & - & - & - & - & - & - & - \\
\hline $\mathrm{SiO}_{2}$ & - & - & - & - & - & - & - & - & - & - & - & - & - & - & - & - & - \\
\hline $\mathrm{NiO}$ & + & - & - & - & - & - & - & - & - & + & - & - & - & - & - & - & + \\
\hline $\mathrm{CO}_{3} \mathrm{O}_{4}$ & + & - & - & - & - & - & - & + & - & + & - & - & - & - & - & - & - \\
\hline $\mathrm{Cr}_{2} \mathrm{O}_{3}$ & - & - & - & - & - & - & - & + & - & - & - & - & - & - & - & - & - \\
\hline $\mathrm{ZnO}$ & + & + & + & + & + & - & - & + & - & + & + & + & + & - & - & + & $\mathrm{N} / \mathrm{A}$ \\
\hline $\mathrm{CuO}$ & + & + & + & + & - & + & - & + & + & + & - & - & + & - & - & + & - \\
\hline Accuracy & & $6 / 9$ & $6 / 9$ & $6 / 9$ & $5 / 9$ & $5 / 9$ & $4 / 9$ & $7 / 9$ & $5 / 9$ & $8 / 9$ & $5 / 9$ & $5 / 9$ & $6 / 9$ & $3 / 9$ & $5 / 9$ & $6 / 9$ & $5 / 8$ \\
\hline False positive & & $0 / 9$ & $0 / 9$ & $0 / 9$ & $1 / 9$ & $0 / 9$ & $0 / 9$ & $1 / 9$ & $0 / 9$ & 0/9 & 0/9 & $0 / 9$ & $0 / 9$ & $1 / 9$ & 0/9 & $0 / 9$ & $0 / 8$ \\
\hline False negative & & $3 / 9$ & $3 / 9$ & $3 / 9$ & $3 / 9$ & $4 / 9$ & $5 / 9$ & $1 / 9$ & 4/9 & $1 / 9$ & $4 / 9$ & $4 / 9$ & $3 / 9$ & $5 / 9$ & $4 / 9$ & $3 / 9$ & $3 / 8$ \\
\hline
\end{tabular}

The highest dose for CuO NP was $3 \mathrm{~cm}^{2} / \mathrm{mL}$

${ }^{b}$ Cytotoxicity was measured by lactated dehydrogenase (LDH) or trypan blue exclusion assay.

Minimum four independent experiments were performed for each assay.

Statistically significant changes compared to vehicle control were marked as ' + ' and no significant changes were noted as '-'. 
Table 4 Comparison of in vivo lung inflammation data with in vitro assay data based on any dose even implausibly high ones

\begin{tabular}{|c|c|c|c|c|c|c|c|c|c|c|c|c|c|c|c|c|c|}
\hline & \multirow{2}{*}{$\frac{\text { Rat }\left(150 \mathrm{~cm}^{2} / \mathrm{rat}\right)}{\text { granulocytes }}$} & \multicolumn{2}{|c|}{ A549 } & \multicolumn{2}{|c|}{ 16-HBE } & \multicolumn{2}{|c|}{ THP-1 } & \multicolumn{2}{|c|}{ Alveolar mac } & \multicolumn{3}{|c|}{ Differentiated PBMC } & \multicolumn{3}{|c|}{ Differentiated THP- ${ }^{\text {a }}$} & \multirow{2}{*}{$\frac{\text { Combined (A549 + THP-1) }^{\mathrm{a}}}{\mathrm{IL}-8}$} & \multirow{2}{*}{$\frac{\text { Haemolysis }}{\% \text { haemolysis }}$} \\
\hline & & cytotox $^{b}$ & IL-8 & cytotox & IL-8 & cytotox & IL-1 $\beta$ & cytotox & $\overline{I L-1 \beta}$ & cytotox & IL-1 $\beta$ & $\overline{\text { TNF- } a}$ & cytotox & IL-1 $\beta$ & $\overline{\text { TNF- } a}$ & & \\
\hline $\mathrm{CeO}_{2}$ & + & - & - & - & + & - & - & + & - & - & - & - & + & + & + & + & + \\
\hline $\mathrm{TiO}_{2}$-rutile & - & - & - & - & - & - & + & + & + & - & + & + & + & + & + & + & - \\
\hline $\mathrm{CB}$ & - & - & - & - & + & - & - & - & - & + & + & - & - & + & - & - & - \\
\hline $\mathrm{SiO}_{2}$ & - & - & - & - & - & - & - & - & - & - & - & - & - & + & - & - & - \\
\hline $\mathrm{NiO}$ & + & - & - & - & - & - & - & + & - & + & + & - & + & - & + & - & + \\
\hline $\mathrm{CO}_{3} \mathrm{O}_{4}$ & + & - & - & - & - & - & - & + & - & + & - & - & - & + & - & - & + \\
\hline $\mathrm{Cr}_{2} \mathrm{O}_{3}$ & - & + & - & - & - & + & - & + & - & + & + & - & + & + & + & + & - \\
\hline $\mathrm{ZnO}$ & + & + & + & + & + & - & - & + & - & + & + & + & + & - & - & + & N/A \\
\hline $\mathrm{CuO}$ & + & + & + & + & - & + & - & + & + & + & - & - & + & - & - & + & + \\
\hline Accuracy & & $5 / 9$ & $6 / 9$ & $6 / 9$ & $5 / 9$ & $4 / 9$ & $3 / 9$ & $7 / 9$ & $4 / 9$ & $6 / 9$ & $3 / 9$ & $4 / 9$ & $6 / 9$ & $2 / 9$ & $4 / 9$ & $5 / 9$ & $8 / 8$ \\
\hline False positive & & $1 / 9$ & 0/9 & 0/9 & $1 / 9$ & $1 / 9$ & $1 / 9$ & $2 / 9$ & $1 / 9$ & $2 / 9$ & $3 / 9$ & $1 / 9$ & $2 / 9$ & $4 / 9$ & $2 / 9$ & $2 / 9$ & $0 / 8$ \\
\hline False negative & & $3 / 9$ & $3 / 9$ & $3 / 9$ & $3 / 9$ & $4 / 9$ & $5 / 9$ & $0 / 9$ & $4 / 9$ & $1 / 9$ & $3 / 9$ & $4 / 9$ & $1 / 9$ & $3 / 9$ & $3 / 9$ & $2 / 9$ & $0 / 8$ \\
\hline
\end{tabular}

The highest dose for CuO NP was $3 \mathrm{~cm}^{2} / \mathrm{mL}$.

${ }^{b}$ Cytotoxicity was measured by lactated dehydrogenase (LDH) or trypan blue exclusion assay.

The statistically significant changes compared to vehicle control were marked as ' +1 ' and no significant changes were noted as ' - .'. 
differentiation, cells were washed three times with PBS and NPs were treated.

\section{Inhibition of phagocytosis by cytochalasin D}

To evaluate the role of phagocytosis on the proinflammatory cytokine release, we treated cytochalasin D which is a well characterized inhibitor of phagocytosis. After differentiation of THP-1 cells by PMA, $0.2 \mu \mathrm{M}$ of cytochalasin D (Enzo Life Sciences, Exeter, UK) were added to NP suspensions and treated for $24 \mathrm{~h}$. The cell supernatants were then collected for lactate dehydrogenase (LDH) and cytokine measurement.

\section{NP treatment and measurement of cytotoxicity}

Three different doses of NPs were dispersed in FBS first with the volume of $5 \%$ in working solution and cell culture medium was added as described above. NPs were then added to cell cultures and incubated for $24 \mathrm{~h}$. Cytotoxicity was measured using a lactate dehydrogenase (LDH) assay kit (Roche Diagnostics Ltd., Burgess Hill, UK) in the NP-free cell culture supernatant collected by three rounds of centrifugation at $15000 \times g$ for $20 \mathrm{~min}$. Vehicle control and $0.1 \%$ Triton-X treatment were used as a negative and positive control, respectively. The cytotoxicity of NP was expressed by percentage compared to complete cytotoxicity $(0.1 \%$ Triton-X). To evaluate the adsorption of LDH on the NPs, bare NPs (NPs alone) or NPs pre-incubated in 5\% FBS to give them a protein corona were incubated with A549 cell extract rich in LDH and LDH assay was then performed. Briefly, NPs with or without $5 \%$ FBS at the highest doses used in in vitro study $\left(30\right.$ or $300 \mathrm{~cm}^{2} / \mathrm{mL}$ ) were incubated with $0.1 \%$ Triton-X treated A549 cells for $30 \mathrm{~min}$ at room temperature. LDH assay was performed using NP containing-cell lysate solution according to the instruction manual (Roche Diagnostics Ltd.). After colour development, solutions were centrifuged at $15000 \times \mathrm{g}$ for 20 min to get rid of NPs and measured absorbance at $490 \mathrm{~nm}$. As a result, bare NPs showed variable adsorption with some NP adsorbing LDH, whilst NPs with a protein corona showed minimal adsorption (data not shown). Therefore, the adsorption of LDH on the NP with a corona is minimal in this setting. Some metal ions released from NPs are known to inhibit the color development of LDH assay [37]. In our panel of NPs, trypan blue exclusion test was applied to $\mathrm{ZnO}$ and $\mathrm{CuO} \mathrm{NP}$ owing to this interference.

\section{Combined cell culture}

Because one of the critical components of the inflammatory response induced by NPs in the lung is the release of inflammatory mediators in contact with alveolar macrophages, we treated conditioned medium of THP-1 cells to A549 cells by modification of the previously described method [25]. Briefly, differentiated THP-1 cells by PMA as mentioned above were treated with NPs for $24 \mathrm{~h}$. NP-free supernatant was then prepared by three rounds of centrifugation at $15000 \times g$ for $20 \mathrm{~min}$ and treated to A549 cells for $4 \mathrm{~h}$. After $4 \mathrm{~h}$ of incubation, medium was washed with PBS for three times and replaced with fresh DMEM medium and incubated for an additional $20 \mathrm{~h}$.

\section{Measurement of cytokines (IL-1 $\beta$, IL-8, and TNF- $\alpha$ )}

IL-1 $\beta$, IL-8, and TNF- $\alpha$ are pro-inflammatory cytokines correlated with inflammogenic potential of particles [38]. We measured IL-8 protein levels in the supernatant of A549 cells, $16-\mathrm{HBE}$ cells, and combined culture and IL-1 $\beta$ and TNF- $\alpha$ in supernatants of monocytes/macrophages cells (THP-1 cells, PBMDM, and alveolar macrophages) according to the instruction manual (R\&D Systems).

\section{Haemolysis assay}

Haemolysis assay was performed according to the previously described method [29]. Briefly, human red blood cells were incubated with NPs at 30,100 , and $300 \mathrm{~cm}^{2} / \mathrm{mL}$ dispersed in saline without any proteins. Saline and $0.1 \%$ Triton X-100 was used as negative and positive control, respectively. After $30 \mathrm{~min}$ incubation, the amount of released haemoglobin was determined by absorbance at $\lambda=550 \mathrm{~nm}$. ZnO NP was excluded in this assay owing to high binding affinity with haemoglobin [26].

\section{Correlation of in vitro assays with in vivo acute lung inflammogenicity}

To evaluate the correlation of in vitro assays with in vivo toxicity, we used some previously published animal experimental data from our own group $[16,17]$ in order to avoid unnecessary sacrifice of animals. Although in vivo data were published earlier, both studies were performed at the same time with the same batch of NPs. The number of total granulocytes was selected as a marker for acute lung inflammogenicity. For in vitro assays, statistically significant increases in any doses were regarded as "positive" and other cases were regarded as "negative" (i.e. no effect). For in vivo experiments, statistically significant increases in the number of total granulocytes compared to vehicle control were regarded as "positive". Because one of the most important parameter comparing each result was the treatment dose, we compared in vitro assays at $30 \mathrm{~cm}^{2} / \mathrm{mL}$ (the only overlapping dose used for all the particles except in Figures 6 and 7 where $3 \mathrm{~cm}^{2} / \mathrm{mL}$ was the highest dose for $\mathrm{CuO} N \mathrm{NP}$ ) or any dose showing statistical significance.

\section{Statistical analysis}

We conducted minimum 4 individual experiments and all data were expressed as mean \pm standard deviations. 
Data were analyzed using the GraphPad Prism 5 (GraphPad Software, Inc., La Jolla, CA, USA). One-way analysis of variance with post hoc Tukey's pairwise comparisons test was used to compare the differences between groups. A $p$ value of $<0.05$ was considered to be statistically significant.

\section{Competing interests}

The authors declare they have no competing financial interests.

\section{Authors' contributions}

WSC, RD, MB, ILM, WMacN, and KD provided key intellectual input culminating in the conception and design of these studies and aided in the writing of this manuscript. The studies were carried out by WSC who also contributed to the writing of the manuscript. JKL and JJ provided expertise on interpretation of data and both contributed to the writing of the manuscript. All authors read and approved the final manuscript.

\section{Acknowledgement}

Financial support was provided by the Medical Research Council of United Kingdom (MRC G0701323) and 13182KFDA606 from Ministry of Food and Drug Safety.

\section{Author details}

'ELEGI/Colt Laboratory, Centre for Inflammation Research, University of Edinburgh, 47 Little France Crescent, Edinburgh EH16 4TJ, UK. ${ }^{2}$ Department of Medicinal Biotechnology, College of Natural Resources and Life Science, Dong-A University, Busan 604-714, Republic of Korea. ${ }^{3}$ School of Chemistry, West Mains Road, University of Edinburgh, Edinburgh, UK. ${ }^{4}$ Free Radical Research Facility, Department of Diabetes \& Cardiovascular Science, University of the Highlands \& Islands, Centre for Health Science, Inverness, UK. ${ }^{5}$ Department of Toxicological Research, National Institute of Food and Drug Safety Evaluation, Ministry of Food and Drug Safety, Osong 363-700, Republic of Korea.

Received: 8 April 2013 Accepted: 21 October 2013

Published: 25 October 2013

\section{References}

1. Nel AE, Madler L, Velegol D, Xia T, Hoek EM, Somasundaran P, Klaessig F, Castranova V, Thompson M: Understanding biophysicochemical interactions at the nano-bio interface. Nat Mater 2009, 8:543-557.

2. Borm PJ, Robbins D, Haubold S, Kuhlbusch T, Fissan H, Donaldson K, Schins R, Stone V, Kreyling W, Lademann J, et al: The potential risks of nanomaterials: a review carried out for ECETOC. Part Fibre Toxicol 2006, 3:11.

3. Organisation for Economic Co-operation and Development: Nanosafety at the OECD: the first five years 2006-2010. Paris: OECD; 2011.

4. Organisation for Economic Co-operation and Development: Six years of OECD work on the safety of manufactured nanomaterials: achievements and future opportunities. Paris: OECD; 2013.

5. Donaldson K, Borm PJ, Castranova V, Gulumian M: The limits of testing particle-mediated oxidative stress in vitro in predicting diverse pathologies; relevance for testing of nanoparticles. Part Fibre Toxicol 2009, 6:13.

6. Alfaro-Moreno E, Nawrot TS, Vanaudenaerde BM, Hoylaerts MF, Vanoirbeek JA, Nemery B, Hoet PH: Co-cultures of multiple cell types mimic pulmonary cell communication in response to urban PM10. Eur Respir $J$ 2008, 32:1184-1194

7. Park EK, Jung HS, Yang HI, Yoo MC, Kim C, Kim KS: Optimized THP-1 differentiation is required for the detection of responses to weak stimuli. Inflamm Res 2007, 56:45-50.

8. Sohaebuddin SK, Thevenot PT, Baker D, Eaton JW, Tang L: Nanomaterial cytotoxicity is composition, size, and cell type dependent. Part Fibre Toxicol 2010, 7:22

9. Kroll A, Dierker C, Rommel C, Hahn D, Wohlleben W, Schulze-Isfort C, Gobbert C, Voetz M, Hardinghaus F, Schnekenburger J: Cytotoxicity screening of 23 engineered nanomaterials using a test matrix of ten cell lines and three different assays. Part Fibre Toxicol 2011, 8:9.

10. Sayes $C M$, Reed KL, Warheit DB: Assessing toxicity of fine and nanoparticles: comparing in vitro measurements to in vivo pulmonary toxicity profiles. Toxicol Sci 2007, 97:163-180.
11. Editorial: The dose makes the poison. Nat Nanotechnol 2011, 6:329.

12. Duffin $R$, Tran $L$, Brown D, Stone $V$, Donaldson K: Proinflammogenic effects of low-toxicity and metal nanoparticles in vivo and in vitro: highlighting the role of particle surface area and surface reactivity. Inhal Toxicol 2007, 19:849-856.

13. Fubini B, Ghiazza M, Fenoglio I: Physico-chemical features of engineered nanoparticles relevant to their toxicity. Nanotoxicology 2010, 4:347-363.

14. Oberdorster G, Maynard A, Donaldson K, Castranova V, Fitzpatrick J, Ausman K, Carter J, Karn B, Kreyling W, Lai D, et al: Principles for characterizing the potential human health effects from exposure to nanomaterials: elements of a screening strategy. Part Fibre Toxicol 2005, 2:8.

15. Johnston HJ, Hutchison G, Christensen FM, Peters S, Hankin S, Stone V: A review of the in vivo and in vitro toxicity of silver and gold particulates: particle attributes and biological mechanisms responsible for the observed toxicity. Crit Rev Toxicol 2010, 40:328-346.

16. Cho WS, Duffin R, Poland CA, Howie SE, MacNee W, Bradley M, Megson IL, Donaldson K: Metal oxide nanoparticles induce unique inflammatory footprints in the lung: important implications for nanoparticle testing. Environ Health Perspect 2010, 118:1699-1706.

17. Cho WS, Duffin R, Bradley M, Megson IL, MacNee W, Howie SEM, Donaldson $\mathrm{K}: \mathrm{NiO}$ and $\mathrm{CO}_{3} \mathrm{O}_{4}$ nanoparticles induce lung DTH-like responses and alveolar lipoproteinosis. Eur Respir J 2012, 39:546-557.

18. Cho WS, Duffin R, Poland CA, Duschl A, Oostingh GJ, Macnee W, Bradley M, Megson IL, Donaldson K: Differential pro-inflammatory effects of metal oxide nanoparticles and their soluble ions in vitro and in vivo; zinc and copper nanoparticles, but not their ions, recruit eosinophils to the lungs. Nanotoxicology 2012, 6:22-35.

19. Bian SW, Mudunkotuwa IA, Rupasinghe T, Grassian VH: Aggregation and dissolution of $4 \mathrm{~nm} \mathrm{ZnO}$ nanoparticles in aqueous environments: influence of $\mathrm{pH}$, ionic strength, size, and adsorption of humic acid. Langmuir 2011, 27:6059-6068.

20. Studer AM, Limbach LK, Van Duc L, Krumeich F, Athanassiou EK, Gerber LC, Moch H, Stark WJ: Nanoparticle cytotoxicity depends on intracellular solubility: comparison of stabilized copper metal and degradable copper oxide nanoparticles. Toxicol Lett 2010, 197:169-174.

21. Yazdi AS, Guarda G, Riteau N, Drexler SK, Tardivel A, Couillin I, Tschopp J: Nanoparticles activate the NLR pyrin domain containing 3 (NIrp3) inflammasome and cause pulmonary inflammation through release of IL-1alpha and IL-1beta. Proc Natl Acad Sci USA 2010, 107:19449-19454.

22. Hornung V, Bauernfeind F, Halle A, Samstad EO, Kono H, Rock KL, Fitzgerald KA, Latz E: Silica crystals and aluminum salts activate the NALP3 inflammasome through phagosomal destabilization. Nat Immunol 2008, 9:847-856.

23. Totlandsdal Al, Refsnes M, Skomedal T, Osnes JB, Schwarze PE, Lag M: Particle-induced cytokine responses in cardiac cell cultures-the effect of particles versus soluble mediators released by particle-exposed lung cells. Toxicol Sci 2008, 106:233-241.

24. Shaw CA, Robertson S, Miller MR, Duffin R, Tabor CM, Donaldson K, Newby DE, Hadoke PW: Diesel exhaust particulate-exposed macrophages cause marked endothelial cell activation. Am J Respir Cell Mol Biol 2010, 44:840-851.

25. Jimenez LA, Drost EM, Gilmour PS, Rahman I, Antonicelli F, Ritchie $H$, MacNee W, Donaldson K: PM(10)-exposed macrophages stimulate a proinflammatory response in lung epithelial cells via TNF-alpha. Am J Physiol Lung Cell Mol Physiol 2002, 282:L237-L248.

26. Cho WS, Duffin R, Thielbeer F, Bradley M, Megson IL, Macnee W, Poland CA, Tran CL, Donaldson K: Zeta potential and solubility to toxic ions as mechanisms of lung inflammation caused by metal/metal oxide nanoparticles. Toxicol Sci 2012, 126:469-477.

27. Donaldson K, Schinwald A, Murphy F, Cho WS, Duffin R, Tran L, Poland C: The biologically effective dose in inhalation nanotoxicology. Acc Chem Res 2013, 46(3):723-732.

28. Thielbeer F, Donaldson K, Bradley M, Johansson EM, Cho WS, Duffin R, Megson IL, Macnee W: Surface functionalization affects the zeta potential, coronal stability and membranolytic activity of polymeric nanoparticles. Nanotoxicology. in press.

29. Lu S, Duffin R, Poland C, Daly P, Murphy F, Drost E, Macnee W, Stone V, Donaldson K: Efficacy of simple short-term in vitro assays for predicting the potential of metal oxide nanoparticles to cause pulmonary inflammation. Environ Health Perspect 2009, 117:241-247.

30. Casals E, Puntes VF: Inorganic nanoparticle biomolecular corona: formation, evolution and biological impact. Nanomedicine (Lond) 2012, 7(12):1917-1930. 
31. Maiorano G, Sabella S, Sorce B, Brunetti V, Malvindi MA, Cingolani R, Pompa PP: Effects of cell culture media on the dynamic formation of proteinnanoparticle complexes and influence on the cellular response. ACS Nano 2010, 4(12):7481-7491.

32. Macickova T, Navarova J, Urbancikova M, Horakova K: Comparison of isoproterenol-induced changes in lysosomal enzyme activity in vivo and in vitro. Gen Physiol Biophys 1999, 18 Spec No:86-91.

33. Horie M, Nishio K, Fujita K, Kato H, Nakamura A, Kinugasa S, Endoh S, Miyauchi A, Yamamoto K, Murayama H, et al: Ultrafine NiO particles induce cytotoxicity in vitro by cellular uptake and subsequent $\mathrm{Ni}(\mathrm{II})$ release. Chem Res Toxicol 2009, 22:1415-1426.

34. Ogami A, Morimoto Y, Myojo T, Oyabu T, Murakami M, Todoroki M, Nishi K, Kadoya C, Yamamoto M, Tanaka I: Pathological features of different sizes of nickel oxide following intratracheal instillation in rats. Inhal Toxicol 2009, 21:812-818

35. Cozens AL, Yezzi MJ, Kunzelmann K, Ohrui T, Chin L, Eng K, Finkbeiner WE, Widdicombe JH, Gruenert DC: CFTR expression and chloride secretion in polarized immortal human bronchial epithelial cells. Am J Respir Cell Mol Biol 1994, 10(1):38-47.

36. Dransfield I, Buckle AM, Savill JS, McDowall A, Haslett C, Hogg N: Neutrophil apoptosis is associated with a reduction in CD16 (Fc gamma RIII) expression. J Immunol 1994, 153:1254-1263.

37. Kroll A, Pillukat MH, Hahn D, Schnekenburger J: Current in vitro methods in nanoparticle risk assessment: limitations and challenges. Eur J Pharm Biopharm 2009, 72:370-377.

38. Monteiller C, Tran L, MacNee W, Faux S, Jones A, Miller B, Donaldson K The pro-inflammatory effects of low-toxicity low-solubility particles, nanoparticles and fine particles, on epithelial cells in vitro: the role of surface area. Occup Environ Med 2007, 64:609-615.

doi:10.1186/1743-8977-10-55

Cite this article as: Cho et al:: Predictive value of in vitro assays depends on the mechanism of toxicity of metal oxide nanoparticles. Particle and Fibre Toxicology 2013 10:55.

\section{Submit your next manuscript to BioMed Central and take full advantage of:}

- Convenient online submission

- Thorough peer review

- No space constraints or color figure charges

- Immediate publication on acceptance

- Inclusion in PubMed, CAS, Scopus and Google Scholar

- Research which is freely available for redistribution 